\title{
EMPYEMA WITH GIANT DILATATION OF THE GALLBLADDER
}

\author{
Empiema com dilatação gigante da vesícula biliar \\ André Luiz Santos RODRIGUES, Marcelino Ferreira LOBATO, Carla Andrea Ribeiro BRAGA, \\ Lucas Crociati MEGUINS, Daniel Felgueiras ROLO
}

ABCDDV/599

Rodrigues ALS, Lobato MF, Braga CAR, Meguins LC, Rolo DF. Empyema with giant dilatation of the gallbladder. ABCD Arq Bras Cir Dig. 2008;21(2):90-1

ABSTRACT - Introduction - Gallbladder empyema is a serious complication of acute cholecystitis being peritonitis and sepsis it's main clinical consequences. Organ giant volume is rare specially with no relevant symptoms. Case report - Man 56-year-old with mild abdominal pain on the right hypochondrium, palpable gallbladder and ultrasound images revealing cholelithiasis. At surgery, there was a giant dilatation of the gallbladder with $580 \mathrm{~mL}$ of purulent bile. Cholecystectomy was carried out without post-operative complications. Conclusion - Early cholecystectomy should always be realized in patients presenting symptoms of gallbladder empyema no matter the size of it.

HEADINGS - Empyema of the gallbladder. Cholecystectomy. Surgery.

\section{INTRODUCTION}

Empyema of the gallbladder (EG) is a complication that may occur during the natural history of acute cholecystitis ${ }^{1,5}$. Cystic duct obstruction and secondary bile infection may lead to dilatation of the organ with empyema formation. In $30 \% \mathrm{EG}$ is not diagnosed preoperatively and in these cases is associated with higher morbidity and mortality ${ }^{1,7}$.

This report is related to a patient with palpable gallbladder on the right hypochondrium and surgery revealed to be EG with giant dilatation of the gallbladder.

\section{CASE REPORT}

A 56-year-old man looked for assistance in an external ambulatory service with history of mild abdominal pain on the right hypochondrium. There were no other morbid antecedents of interest. The physical examination revealed a palpable mass on the right upper quadrant of the abdomen probably due to the gallbladder. Routine blood investigation showed a marked leukocytosis and normal hepatic function tests. Ultrasound revealed a large distension of the gallbladder with cholelithiasis. Cholecystectomy was

Disivion of General Surgery, Department of Surgery, Hospital de Clínicas “Gaspar Vianna”, Belém, Pará, Brazil.

Address for correspondence: André Luiz Santos Rodrigues E-mail: santosrodrigues@superig.com.br indicated and operation revealed an giant dilatation of the gallbladder (Figure 1). The gallbladder fundus aspiration took out $580 \mathrm{~mL}$ of purulent bile and a calculus was impacted in the cystic duct's orifice. The fundus-cystic cholecystectomy without previous ligature of the cystic duct and artery was carried out (Figure 2). The patient had a good post-operative evolution and systemic Ertapenen $1 \mathrm{~g}$ daily was carried out for five days. The patient was discharged from the hospital in good health conditions on the sixth post-operative day.

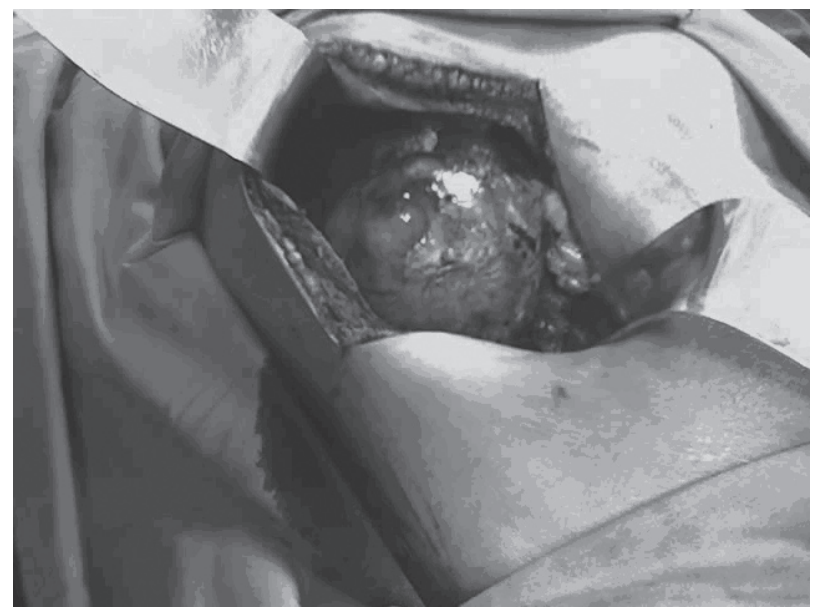

FIGURE 1 - Intra-operative aspect revealing the giant dilatation of the gallbladder 


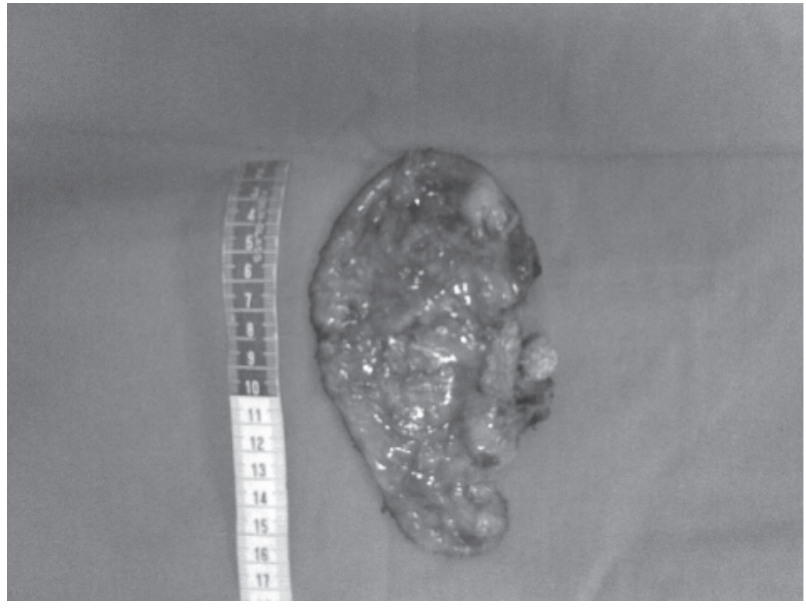

FIGURE 2 - Specimen of the cholecystectomy: greatly dilated gallbladder with approximately $16 \mathrm{~cm}$ in length.

\section{DISCUSSION}

EG is a serious complication of acute cholecystitis demanding emergency treatment and associated with higher morbidity and mortality ${ }^{1}$. The impaction of a stone and the obstruction of the cystic duct may cause stagnation and bile contamination, leading to dilatation of the organ ${ }^{1,5}$, but rarely so big as in this case.

In normal conditions, the capacity of the gallbladder is estimated to be about $50 \mathrm{~mL}^{3}$. In this case, it was removed $580 \mathrm{~mL}$ of purulent bile making it an unusual case.

The signs and symptoms of EG are indistinguishable from acute cholecystitis ${ }^{5,7}$. The EG may only be recognized after the appearance of Charcot's triad, with or without peritonitis and sepsis ${ }^{5}$. Therefore, in a few cases, these symptoms may not be present during the medical interview and physical examination ${ }^{2}$. An important fact that may explain the reason of increased incidence of $E G$ in the amazonic population, is the delay in seeking medical care and the patients reluctance in early cholecystectomy.

The ultrasonographic findings of the EG are increased thickness of the gallbladder's wall due to phlogosis and periparietal halo due to the surrounding edema ${ }^{4,6}$.

The treatment of the EG is the removal of the inflamed gallbladder and its contents by open or laparoscopic early cholecystectomy and administration of antibiotics ${ }^{3,5}$. The intra-operative cholangiography may be performed when there is dilatation of the common bile duct or when the surgeon decides it is necessary ${ }^{5}$. In the present case, the open fundus-cystic cholecystectomy without previous ligature of the cystic duct and cystic artery was carried out in order to avoid the possibility of a iatrogenic lesion of the common bile duct during the dissection of the gallbladder because of the giant dilatation.

The gallbladder's percutaneous drainage guided by ultrasound can be performed in patients in bad clinical conditions $\mathbf{s}^{5,8,9,10}$.

\section{CONCLUSION}

Early cholecystectomy should always be realized in patients presenting symptoms of gallbladder empyema, no matter the size of it.

Rodrigues ALS, Lobato MF, Braga CAR, Meguins LC, Rolo DF. Empiema com dilatação gigante da vesícula biliar. ABCD Arq Bras Cir Dig. 2008;21(2):90-1

RESUMO - Introdução - Empiema de vesicular é complicação séria da colecistite aguda podendo levar à peritonite e sepse. O aspeto gigante do volume do órgão e seu conteúdo líquido é que fazem deste caso rara citação na literatura. Relato do caso - Homem com 56 anos apresentou-se em ambulatório médico eletivo com dor abdominal leve em hipocôndrio direito. O exame clínico mostrou vesícula biliar palpável e imagens ultrassonográficas confirmaram colecistolitíase. Indicada ressecção cirúrgica, o ato operatório mostrou gigante dilatação da vesícula com conteúdo de $580 \mathrm{~mL}$ de líquido purulento. Colecistectomia laparotômica foi realizada sem intercorrências per-operatórias. Conclusão - Colecistectomia precoce deve ser sempre o tratamento de escolha nos casos de colecistectomia com componente inflamatório ou infeccioso independentemente do tamanho no órgão.

DESCRITORES - Empiema de vesísula biliar. Colecistectomia. Cirurgia.

\section{REFERENCES}

1. Bedirli A, Sakrak O, Sözüer EM, Kerek M, Güler I. Factors effecting the complications in the natural history of acute cholecystitis. Hepatogastroenterology 2001; 48(41):1275-1278.

2. Berardi RS, Jarasviroj N, Peterson C, Murakami K. Empyema necessitatis of the gallbladder: a case report. Int Surg 1979;64(1):31-33.

3. Callander CL. Surgical Anatomy. 2.ed. WB Saunders Company, 1942.

4. Caselli M, Vita G, Zucchi F. Ultrasonic differentiation between mucocele and empyema of gallbladder. Lancet 1984;1(8384):1022.

5. Fry DE, Cox RA, Harbrecht PJ. Empyema of the gallbladder: a complication in the natural history of acute cholecystitis. Am J Surg 1981; 141(3):366-369.

6. Kane RA. Ultrasonographic diagnosis of gangrenous cholecystitis and empyema of the gallbladder. Radiology 1980;134(1):191-194.

7. Krogh J. Empyema of the gallbladder: a case with unusual presentation. Acta Chir Belg 1989;89(4):204-205.
8. Lim MS, Davaraj B, Kandasami P. Endoscopic drainage of empyema of the gallbladder through a concurrent cholecystoduodenal fistula. Asian J Surg 2006;29(1):55-57.

9. Radder RW. Ultrasonically guided percutaneous catheter drainage for gallbladder empyema. Diagn Imaging 1980;49(6):330-333.

10. Tseng LJ, Tsai CC, Mo LR, Lin RC, Kuo JY, Chang KK, Jao YTFN. Palliative percutaneous transhepatic gallbladder drainage of gallbladder empyema before laparoscopic cholecystectomy. Hepatogastroenterology 2000;47(34):932936. 